\title{
R-80 NEW REGIONAL AIRCRAFT FOR INDONESIAN MARKET
}

\author{
Hani Dwi Kartika Putri ${ }^{1}$, Chyntia Glori Rosauli Tobing ${ }^{2}$, Basri \\ Fahriza $^{3}$ \\ 1. STMT Trisakti, 2. STMT Trisakti, 3. STMT Trisakti \\ $\triangle$ corresponding author: chyntiagrt@gmail.com
}

\begin{abstract}
R-80 is a regional passenger aircraft with twin-turboprop engine designed by PT Regio Aviasi Industry. In this era, R-80 existence in Indonesian aviation market is still not perceived, while the purpose of creating R-80 is to supply local demand. Meanwhile, most of airlines in Indonesia prefer using ATR72 as their fleet. If we look at Indonesia's airports condition, plenty airports runaways length are less than 1400 meters. R-80, need only 1,200 meters for take off and landing, is really suitable to use in Indonesia. R-80 also has a bigger fuselage than ATR-72; make it more efficient in carrying passengers. R- 80 fuel capacity is less than ATR but it can carry more payload than ATR, it makes R-80 has less fuel consumption. This journal use SWOT analysis as a method to identify the internal and external factors that will affect the company's project.

Keywords: regional aircraft, aviation industry, ATR 72, R-80, Indonesia
\end{abstract}

\section{Introduction}

Indonesia is an achipelago country that consists of many islands that seperated by sea. With more 250 million people living on 17.000 islands,Indonesia is suitable for air transport expansion (Kemis Martono. Sandriana Marina. Aditya Wardana, 2016). Therefore, we rely on air transportation as a main transportation mode to connect each islands (Gunadi \& K, 2016). Air Transportation is the most efficient and comfortable mode to travel in Indonesia (Ir. Prasadja Ricardianto. Dr.Gunawan Djajaputra. \& Prof.Dr.Martono, 2017). As we know, there are lot of airports in Indonesia which can only accomodate small aircraft like regional aircraft. Regional aircraft is an aircraft that used for flying for regional area with minimum capacity of 30 seats and 100 seats at the maximum.(Clean Sky, n.d.) The examples of regional aircraft are ATR from France, Bombardier from Canada and N250 from Indonesia which has been enchanced into N219 by Indonesian Aerospace (previously, PT IPTN). N250 was first introduced in 1995. And because of the monetary crisis in 1998, Indonesia's aviation industry was stumped. However, in 2012, Indonesian Aerospace rose and created a new concept as in N219. N219 did 
its first flight on August 16th 2017 (Berita Satu, 2013). Besides Indonesian Aerospace, we also have PT. Regio Aviasi Industri with their R-80 which until recent year has accomplished their protoytpe aircraft and targeted to make its first flight on 2020. In the last few years the needs of goods and services is continue to increase, this conditon is directly proportional compared with the increasing amount of national aviation industry (MB Tampubolon Eddy Suhaedi Robby Ariyanto, 2016). Likewise, Indonesian tourism industry is being paid serious attention by the government (Juliater Simarmata, Yuliantini, 2017) and makes Aviation Industries in Indonesia, is rapidly growing to reach it's immense future potential (Indra Yuzal Lira Agushinta Adi Wiratama, 2016) (Gunadi \& K, 2016).

70 percent of regional flights in Indonesia with an average distance of 350 kilometers are served by a 50-seater ATR 42, or a 78-seater ATR 72 aircraft, in fact the aim of R-80 is to make connection between one point to another easier, especially in Indonesia (Chandra, 2017b). Until now, promotion of $\mathrm{R}-80$ is still hardly heard in public even in aviation business circle, while the purpose of creating R-80 is to supply local demand.

Based on the information described, authors are interested to conduct a research to discover the superiority of R-80, and to compare it to ATR which has been used by exsisting operators. An integeration of Aviation Industry among the Southeast Asia countries will create a new strength in Aviation World. Because Indonesia is the only country in Southeast Asia that has manufacturing capabilities (to produce aircraft). In the other hand, Malaysia is good in maintenance, Thailand is well-known for its' aircraft MRO (Maintenance, Repair and Overhaul) service, and the Philippines has a good pilot training program. This will be an ideal project for Southeast Asia regional collaboration.

\section{Method}

To analyze the problem, reserchers used method of data analysis by using SWOT Analysis with IE Matrix. SWOT analysis was used to identify the internal and external factors that will affect the R-80's project. The company's strengths and weaknesses from internal factors to compete the 
competitors were also explored. In this case, R-80 was compared with ATR 72 and the result was to perceive the most suitable aircraft to operate in Indonesia.

\section{Discussion and Result}

R-80 is a regional passenger aircraft with twin-turboprop engine designed by PT Regio Aviasi Industry. Mr Habibie as a founder of this project, made a unique choise to create turboprop engine aircraft, because nowadays many people and operators prefer to use Jet Engine than Turboprop Engine (Laksono, 2015). Turboprop is the most efficient engine to fly at speeds below $725 \mathrm{~km} / \mathrm{h}$ (450 mph, 390 knots) with $40-60 \%$ less fuel efficient than narrow- and wide-body counterparts because, the jet speed from the turbine/propeller is relatively low (Laksono, 2015) (Raffi Babikian, Stephen P., Lukachko, 2002). The excellence of R-80 is fit in Indonesian's market that has ample number of airport runways length are less than 1400 meters. Providentially, R-80 can take off and landing in short runway not more than 1200 meters (Moshe Givoni; Rietveld, 2009).

The main competitor of R-80 as an aircraft with turboprop engine is ATR-72. Some advantages that R-80 has compared to ATR-72 are; less fuel consumption up to $10 \%-15 \%$. R-80 also has $10 \%$ bigger fuselage and $25 \%$ longer than ATR-72. Moreover, R-80 has more capacity (100-110 passenger) than ATR-72 (70 passenger) (Laksono, 2015).

This aircraft is designed by Indonesia aircraft maestro, Mr. Crack, also known as B.J Habibie and his son Ilham Habibie. The estimated official price of this aircraft is US\$20-25. With a superior specification compared to the same kind of aircraft in his class, and an economic price, this aircraft has already been ordered for 125 units, although the production still in process and planned to have his first flight in 2021. As an Indonesian, we should be proud with R-80, the aircraft that made by us, for us and used by us.((Laksono, 2015)

The process of making R-80 aircraft will be manufactured at Kertajati, Majalengka, West Java. It is located in Aerocity Bandara Kertajati industrial 
area or also known as West Jawa International Airport. Aerocity Bandara Kertajati industrial area is chosen as the manufacturing of the aircraft because it will be easier to do the first flight there (Chandra, 2017).

R-80 can carry 80 until 92 passengers in single configuration class and operated by 2 flight crew members. R-80 is N-250 modified aircraft in order to make Indonesian Aviation Industry awaken. R-80 project was launched in 2012 and the first prototype will be launched in 2019. (Chandra, 2017). In Indonesia, many airlines already ordered R-80, among others are NAM Air, Trigana and Aviastar (Finance, 2015) and the users of ATR 72 are Garuda Indonesia,Wings Air and NAM Air (Indonesia, n.d.).

\section{A. Strength}

R-80 has efficient fuel consumption therefore, compared to its competitor,R-80 can carry less fuel than ATR-72. R-80 has bigger fuselage than ATR 72.With a bigger fuselage, R-80 can carry more payload than ATR-72, faster cruise speed than ATR-72 (Gao, 2014). R-80 can save 10\%$15 \%$ fuel than ATR-72. R-80 answers market needs in the future, the number of passengers will increased so we need a bigger aircraft.

$\mathrm{R}-80$ is local product, by being a local product, the operators don't have to pay for expensive import price. Another benefit by being alocal product is increasing product quality. Developing local industries will increase their quality of product and compete with foreign companies. If the quality of local product increase it can reduce the using of foreign product.

\section{B. Weakness}

Because is R-80 a new product, many people still don't know that Indonesia has our own aircraft (R-80), because of this weak brand image, many airlines prefer using foreign aircraft.

Similar type of aircraft in its class rapidly evolve. Other comepetitors like ATR or Bombardier, always have new idea to upgrade their specification and technology. But R-80 still in progress to make the aircraft. 
After R-80 do its first flight, if the company doesn't think what will they do next, R-80 will just left behind the other.

\section{Opportunities}

The opportunities of R-80 are, this project can expand Indonesia aviation industry existence.With R-80 sold in market, Indonesia aviation industry is being recognized in foreign country; therefore it will increase Indonesia aviation industry existence.

Even when the prototype of R-80 not yet completed, there are a lot of airline that already ordered it. With R-80 superior specification, it will answers international market demand in the future (ZHANG, 2010).

D. Threat

R-80 Still didn't have an aircraft prototype and still had a fund problem.Because of the company still don't have the prototype of the aircraft and this project still lack of fund. R-80 is a private company project, therefore they don't get funding support from government. PT Regio Aviasi Industry make fundraising program to run $\mathrm{R}-80$ project. Because of this condition, many airline still thinking to take R-80 as their fleets.

\section{Conclusion}

Table 1. Matrix IFE

\begin{tabular}{|c|c|c|c|c|}
\hline No. & Main Factor & Weight & Rating & Weighted Value \\
\hline \multicolumn{5}{|c|}{ Strength } \\
\hline 1. & Efficient Fuel Consumption & 0.25 & 4 & 1 \\
\hline 2. & Bigger fuselage than ATR & 0.19 & 3 & 0.57 \\
\hline 3. & Carry more passenger & 0.25 & 3 & 0.75 \\
\hline 4. & $\mathrm{R}-80$ as a local product & 0.30 & 4 & 1.24 \\
\hline \multicolumn{5}{|c|}{ Weakness } \\
\hline 1. & Still not have prototype & 0.5 & 3 & 0.15 \\
\hline 2. & Weak Brand Image & 0.5 & 2 & 0.10 \\
\hline \multicolumn{2}{|c|}{ Total } & 1 & & 3.81 \\
\hline
\end{tabular}


Table 2. Matrix EFE

\begin{tabular}{|c|c|c|c|c|}
\hline No. & Main Factor & Weight & Rating & Weighted Value \\
\hline \multicolumn{5}{|c|}{ Opportunities } \\
\hline 1. & $\begin{array}{l}\text { Rise Indonesia Aviation } \\
\text { Industries Existence }\end{array}$ & 0.56 & 3 & 1.71 \\
\hline 2. & International market demand & 0.43 & 3 & 1.29 \\
\hline \multicolumn{5}{|c|}{ Threat } \\
\hline 1. & Funding Problem & 0.5 & 3 & 0.15 \\
\hline 2. & $\begin{array}{l}\text { Same kind of aircraft that } \\
\text { rapidly evolve }\end{array}$ & 0.5 & 3 & 0.15 \\
\hline Total & & 1 & & 3.30 \\
\hline
\end{tabular}

Table 3. Matrix IE

IFE Matrix

\begin{tabular}{c||cccc|}
\multirow{2}{*}{ EFE } & IFE: 3.86 & STRONG & AVERAGE & WEAK \\
Matrix & EFE: 3.25 & $(3.00-4.00)$ & $(2.00-2.99)$ & $(1.00-1.99)$ \\
\cline { 2 - 5 } & HIGH & I & II & III \\
$(\mathbf{3 . 0 0 - 4 . 0 0})$ & Grow & and & Maintain \\
\cline { 2 - 4 } MEDIUM & IV & V & VI \\
$(\mathbf{2 . 0 0 - 2 . 9 9 )}$ & Build & and & Harvest \\
LOW & VII & VIII & IX \\
$(\mathbf{1 . 0 0 - 1 . 9 9 )}$ & Hold & or & Digest \\
\hline
\end{tabular}

From the Table above, PT Regio Aviasi Industri is located in first quadrant, or in growing and sustain position. By being in first quadrant; PT Regio Aviasi Industry use Market Penetration, Market Development, Product Development and Integrative as their strategy.

Based on the information and summaries described, Indonesia new type of aircraft is a magnificient innovation to develop local aviation industry. R-80 has more capacity, payload and higher speed than ATR. Thus, R-80 can carry more passengers and cargo, less fuel consumption and 
efficient flight time. Besides that, R-80 is local product. Therefore, Indonesia has already produced aircraft by its own, if operators decide to recondition their fleet from ATR to R-80, they can reduce the cost. Because we dont need to buy imported aircraft.

PT. Regio Aviasi Industry must ensure the certainty of R-80 project. Hence, the operators convinced to order R-80. It is important to assure Indonesia people know that we have our own aircraft, so R-80 project will get more support and attention. If R-80 already penetrate National market, it also possible go through International market (Summerfield, 2016) .

\section{References}

Berita Satu. (2013). imf. Retrieved from http://www.beritasatu.com/nasional/92377-habibie-imf-ingin-matikanindustri-pesawat-nasional.html

Chandra, A. A. (2017). location $r$ 80. detikFinance. Retrieved from https://finance.detik.com/berita-ekonomi-bisnis/3423960/di-manapesawat-r80-diproduksi-ini-lokasinya

Chandra, A. A. (2017). tujuan r80. Detik Finance. Retrieved from https://finance.detik.com/industri/3589188/mengintip-kecanggihanpesawat-r80-buatan-habibie-di-kemayoran

Clean Sky. (n.d.). No Title. Retrieved November 2, 2017, from http://www.cleansky.eu/regional-aircraft

Finance, D. (2015). r80 PO. Retrieved from https://finance.detik.com/industri/2836191/145-unit-pesawat-r80rancangan-habibie-sudah-dipesan

Gao, S. C. C. K. C. B. C. J. D. Y. (2014). fuel efficiecy. Establishing a Benchmark of Fuel Efficiency for Commercial Airline Operations, 36.

Gunadi, A., \& K, M. (2016). ID condition. Current Indonesian Air Transportation, 9(10).

Indonesia, T. 2. (n.d.). atr users. Retrieved November 10, 2017, from https://www.tiket2.com/blog/tipe-pesawat-yang-dipakai-olehmaskapai-penerbangan-indonesia/

Indra Yuzal Lira Agushinta Adi Wiratama. (2016). ID increase 2. PELAYANAN FASILITAS TERMINAL BAGI PENGGUNA JASA PENERBANGAN, 2, 267.

Ir. Prasadja Ricardianto. Dr.Gunawan Djajaputra., \& Prof.Dr.Martono. (2017). air transport. Air Transport and Tourism in Indonesia, 10(5), 1.

Juliater Simarmata, Yuliantini, and Y. K. (2017). ID tourism. The Influence of Travel Agent, Infrastructure and Accommodation on Tourist Satisfaction, 28, 281.

Kemis Martono. Sandriana Marina. Aditya Wardana. (2016). archipelago id. Domestic Air Transport Regulations in Indonesia, 3, 2. 
Laksono, F. B. (2015). discussion. Retrieved November 9, 2017, from http://www.penggagas.com/pesawat-r80-berbasis-turboproprancangan-maestro-b-j-habibie/

MB Tampubolon Eddy Suhaedi Robby Ariyanto. (2016). increase condition. KEBUTUHAN FREKUENSI PENERBANGAN RUTE JAKARTA JOGYAKARTA - JAKARTA PT INDONESIA AIR ASIA, 2.

Moshe Givoni; Rietveld, P. (2009). runway. Airline's Choice of Aircraft Size - Explanations and Implications, 502.

Raffi Babikian, Stephen P., Lukachko, I. A. W. (2002). fuel. The Historical Fuel Efficiency Characteristics of Regional Aircraft from Technological, Operational, and Cost Perspectives, 8(6), 389.

Summerfield, P. H. (2016). opp. The World of Regional Aircraft Challenges and Opportunities, 98(980).

ZHANG, X. F. T. H. O. A. (2010). pax growth. Air Transport Liberalization and Its Impacts on Airline Competition and Air Passenger Traffic, 49, 27. 